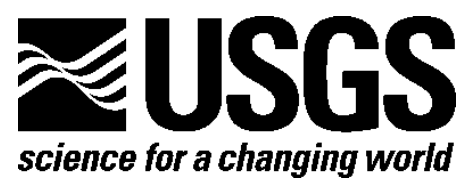

\title{
Preliminary Interpretation of Pre-2014 Landslide Deposits in the Vicinity of Oso, Washington
}

By Ralph A. Haugerud

Open-File Report 2014-1065

U.S. Department of the Interior

U.S. Geological Survey 


\section{U.S. Department of the Interior SALLY JEWELL, Secretary}

\section{U.S. Geological Survey \\ Suzette M. Kimball, Acting Director}

U.S. Geological Survey, Reston, Virginia: 2014

For more information on the USGS-the Federal source for science about the Earth, its natural and living resources, natural hazards, and the environment-visit http://www.usgs.gov or call 1-888-ASK-USGS

For an overview of USGS information products, including maps, imagery, and publications, visit $h$ ttp://www.usgs.gov/pubprod

To order this and other USGS information products, visit http://store.usgs.gov

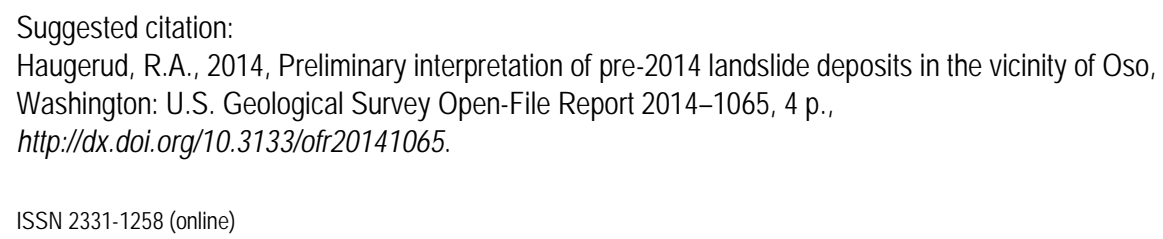

Although this information product, for the most part, is in the public domain, it also may contain copyrighted materials as noted in the text. Permission to reproduce copyrighted items must be secured from the copyright owner. 


\title{
Preliminary Interpretation of Pre-2014 Landslide Deposits in the Vicinity of Oso, Washington
}

\author{
By Ralph A. Haugerud
}

High-resolution topographic surveys allow fairly precise mapping of landslide deposits and their relative ages. Relative ages are determined by cross-cutting relations and the amount of smoothing - more smoothed slide deposits are older — of these deposits. The Tulalip Tribes, in partnership with the Puget Sound Lidar Consortium, acquired a high-resolution lidar (light detection and ranging) survey of the North Fork Stillaguamish River valley in 2013. This report presents a preliminary interpretation of the topography of this area using the lidar data at a scale of $1: 24,000$.

Figure 1 is an elevation model derived from 1:24,000-scale contours on published U.S. Geological Survey (USGS) topographic maps. Resolution is low and artifacts resulting from interpolation of the contours and projection to a raster image are evident. The red cross-hatched area marks the approximate extent of deposits from the March 22, 2014, landslide. A red line with tick marks the approximate position of the March 22 headscarp. Both features were mapped from news photographs and their locations are not precise.

Figure 2 is an elevation model calculated from the 2013 lidar survey. Colored areas show older landslide deposits, distinguished by their relative age: A, youngest to D, oldest. Relative ages are estimated by cross-cutting relations and the amount of smoothing. Each deposit was derived from the adjacent uphill arcuate scarp. Relative ages are valid for adjoining landslide deposits, but do not necessarily indicate simultaneous formation. For example, all deposits of age $\mathrm{B}$ were not created during the same time period. All landslides are younger than the retreat of the Puget lobe of the Cordilleran ice sheet, which in this area probably occurred about 14,000 years ago. Landslides classed as age A include the 2006 Steelhead Haven landslide to the northeast, and the Skaglund Hill landslide to the southwest, which was active in 2006 and 2011. The red cross-hatched area marks the approximate extent of deposits from the March 22, 2014, landslide. A red line with tick marks the approximate position of the March 22 headscarp. Both features were mapped from news photographs.

These interpretations are preliminary and are based entirely on topography. Where younger events (for example, fluvial erosion or deposition) have eroded or buried landslide deposits, their distinctive morphology will not be evident. The actual extent of landslide deposits is probably greater than shown. In a very few locations, morphology may not be diagnostic.

Mapping is only one of several elements in a landslide-hazard assessment. Stratigraphic and chronologic studies are necessary to establish landslide frequencies. Mechanics of past and potential future landslides need to be analyzed to better understand the potential for future failure and the potential for rapid movement. Forecasts of climate change and river meandering may be essential. 
The accompanying geodatabase includes four vector feature classes

- OldLandslideArcs: Arcs delimiting landslide deposits and the limits of the interpreted area

- OldLandslidePolys: Polygons built from OldLandslideArcs and attributed with relative age

- NewLandslidePoly: Approximate extent of the March 22, 2014 landslide deposit

- NewLandslideScarp: Approximate position of headscarp of the March 22, 2014 landslide

Also included in the geodatabase are raster shaded-relief images

- Tulalip2013_nw: Calculated from 2013 lidar topography (available from the Puget Sound Lidar Consortium website under 2013 Tulalip Project)

- NASA2003_nw: Calculated from 2003 lidar topography (available from the Puget Sound Lidar Consortium website under Data from Other Agencies)

- NED13_nw: Calculated from digital topography derived from 1:24,000-scale contours (available from the National Map, 1/3 arc-second National Elevation Dataset) 


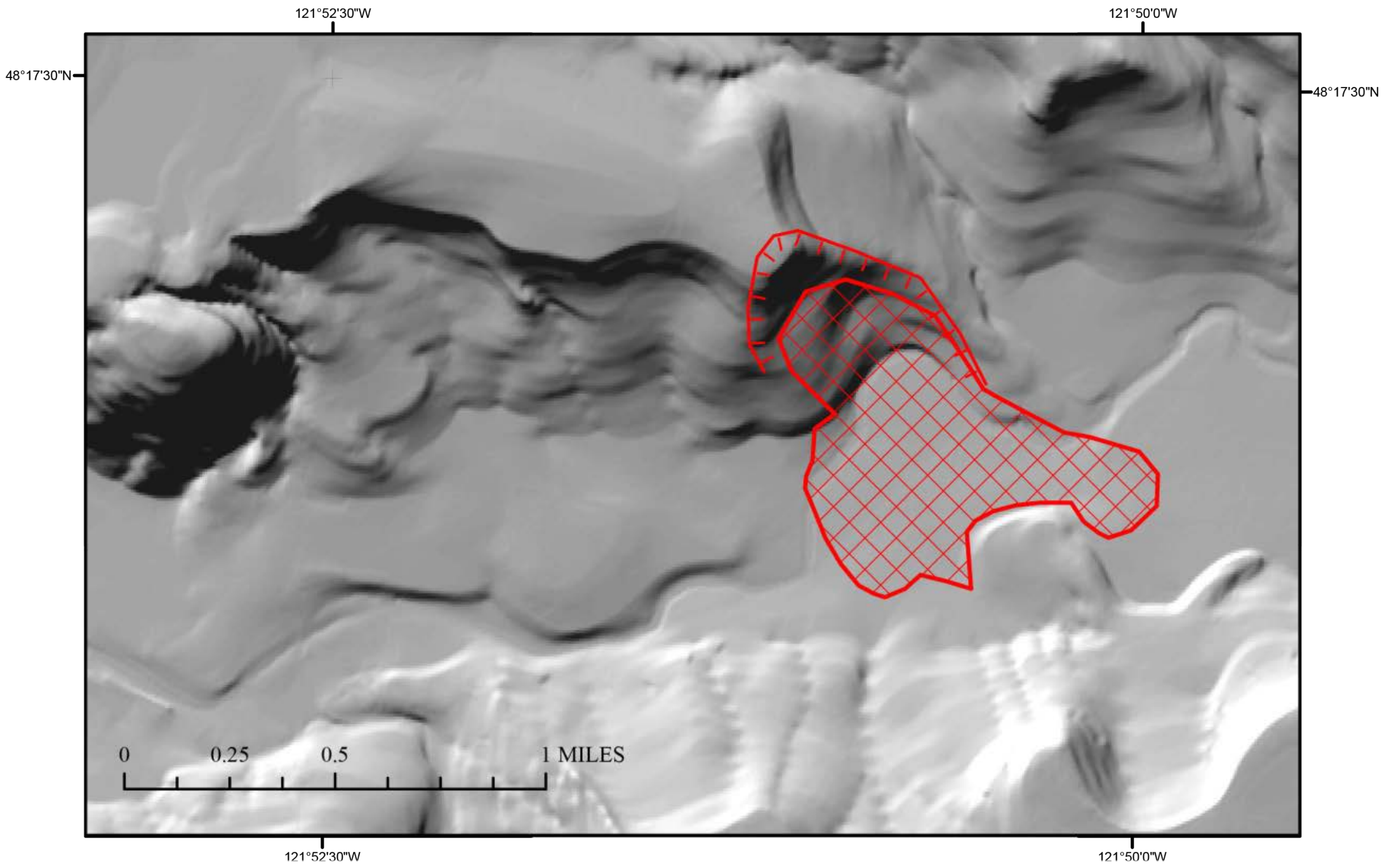

Figure 1. Shaded-relief image of elevation model derived from 1:24,000-scale contours on published U.S. Geological Survey (USGS) topographic maps. The red cross-hatched area marks the approximate extent of deposits from the March 22, 2014, landslide. 


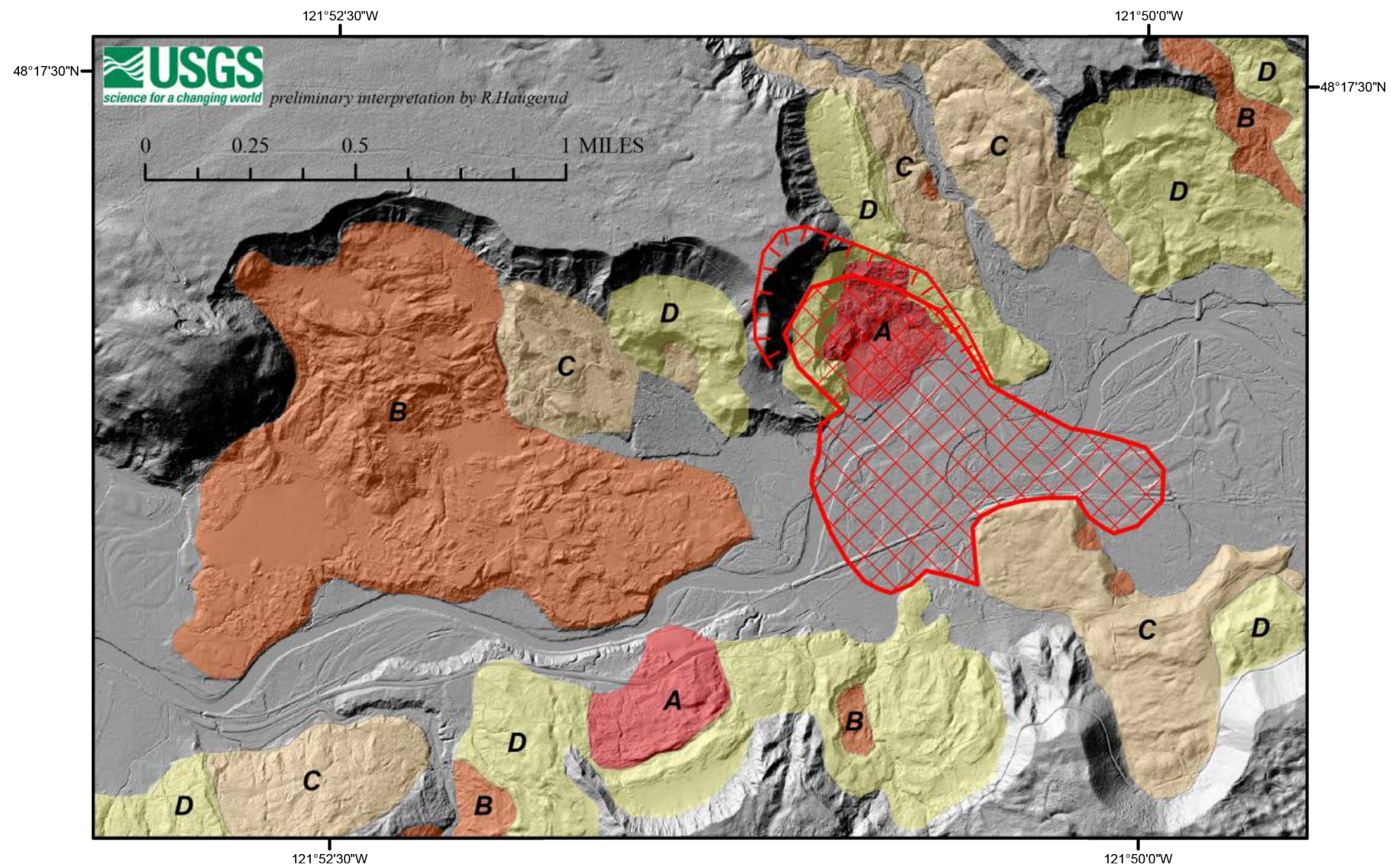

Figure 2. Shaded-relief image calculated from the 2013 lidar survey. Colored areas show older landslide deposits, distinguished by their relative age: A, youngest to D, oldest. The red cross-hatched area marks the approximate extent of deposits from the March 22, 2014, landslide. 